\title{
Morphological and Immunocytochemical Identification of Indoleamine-Accumulating Neurons in the Cat Retina
}

\author{
H. Wässle, T. Voigt, and B. Patel \\ Max-Planck-Institut für Hirnforschung, 6000 Frankfurt/M. 71, Federal Republic of Germany
}

\begin{abstract}
The type and distribution of indoleamine-accumulating neurons were studied in the cat retina. The neurons were characterized by their capacity to take up an exogenous indoleamine, 5,6-dihydroxytryptamine, which could then be visualized using formaldehyde-induced fluorescence. Under direct microscopic control, intracellular injection of Lucifer yellow into the labeled cells revealed that the indoleamineaccumulating neurons comprise 2 distinct morphological types of amacrine cell and 1 class of ganglion cell. The dendritic morphology and retinal distribution of these cells were studied in detail. The proportion of retinal cells that accumulate 5-HT was measured using 5-HT (5-hydroxytryptamine) preloading in vitro and immunocytochemistry with an anti-5-HT antibody. Only 1 type of amacrine cell showed uptake of 5-HT at a concentration of $10^{-7} \mathrm{M}$. Cells containing endogenous 5-HT were not detected by immunocytochemistry.
\end{abstract}

Indoleamine-accumulating neurons in the cat retina were first reported by Ehinger and Florén (1976). A set of neurons that preferentially took up the 5-HT analog 5,6-dihydroxytryptamine, injected into the vitreous body, was identified by fluorescence microscopy with the Falck and Hillarp technique. Similar indoleamine-accumulating neurons have been found in a variety of other mammals (for review, see Ehinger, 1982; Osborne, 1983; Redburn, 1985). The specific uptake of indoleamines into mammalian retinas was later confirmed using either ${ }^{3} \mathrm{H}-5-\mathrm{HT}$ uptake followed by autoradiography (Ehinger and Florén, 1980) or by immunocytochemical staining of 5-HT-accumulating neurons (Osborne et al., 1982; Tornquist et al., 1983; Osborne and Patel, 1984). Although sophisticated biochemical methods have detected the presence of small amounts of 5-HT in mammalian retinas (Osborne et al., 1982; Tornquist et al., 1983), endogenous 5-HT has not yet been localized in mammalian retinal neurons. In contrast, nonmammalian retinas contain much higher concentrations of endogenous 5-HT, which has been localized in a variety of neurons by immunocytochemistry (Osborne et al., 1982; Tornquist et al., 1983; Witkovsky et al., 1984; Weiler and Schütte, 1985; Negishi et al., 1986). The latter findings, together with results from physiological experiments, make 5-HT a likely transmitter in nonmammalian retinas.

Received Sept. 9, 1986; revised Nov. 5, 1986; accepted Nov. 18, 1986.

We wish to thank Felicitas Boij and Martina Koch for skillful technical assistance, Irmgard Odenthal for valuable secretarial services, and Joan Dann for critically reading and improving the English manuscript.

Correspondence should be addressed to Heinz Wässle, Max-Planck-Institut für Hirnforschung, Deutschordenstr. 46, 6000 Frankfurt/M. 71, F.R.G.

Copyright (C) 1987 Society for Neuroscience $0270-6474 / 87 / 051574-12 \$ 02.00 / 0$
Indoleamines are preferentially accumulated by amacrine cells in all mammals. The synaptic organization of these labeled neurons has been extensively studied, and it has been found that their terminals engage in reciprocal synapses with bipolar cell terminals and provide synaptic contacts with other amacrine cells (Ehinger and Holmgren, 1979; Dowling et al., 1980; Holmgren-Taylor, 1982).

However, there is an absence of detailed information concerning the morphological types and density distribution of indoleamine-accumulating neurons in the cat. The present paper provides a description of the dendritic branching pattern and retinal distribution of these neurons. Their morphology was revealed by a technique developed for cholinergic amacrine cells in rabbit retina (Tauchi and Masland, 1984; Vaney, 1984) and involves the intracellular injection of Lucifer yellow into prelabeled neurons. A similar approach was recently used to identify 5-HT-accumulating neurons in rabbit retina (Sandell and Masland, 1986; Vaney, 1986). In the present study, the retinal distribution of these cells was determined from the whole-mount preparations of immunostained cat retinas using an antibody directed against 5-HT (Steinbusch et al., 1983) after in vitro 5-HT uptake.

\section{Materials and Methods}

Uptake of indoleamines. Following neurophysiological experiments done for other projects, 13 cats with otherwise normal eyes were used in uptake studies. The animals were deeply anesthetized with $3 \%$ halothane in a mixture of $70 \%$ nitrous oxide and $30 \%$ carbogen $\left(95 \% \mathrm{O}_{2}, 5 \% \mathrm{CO}_{2}\right)$. In addition, 6 normal cats, which had not been in neurophysiological experiments, were used for this study. They were decply ancsthetized by an intraperitoneal injection of sodium pentobarbital $(40 \mathrm{mg} / \mathrm{kg})$. A small incision was made in the sclera, and, under ophthalmoscopic control, drugs (total volume, $10 \mu$ l) were injected with a Hamilton syringe at several locations within the vitreous. Depending on the experiment, $20 \mu \mathrm{g}$ 5-hydroxytryptamine (5-HT), $20 \mu \mathrm{g}$ 5,6-dihydroxytryptamine $(5,6-\mathrm{DHT})$, or $20 \mu \mathrm{g}$ 5,7-dihydroxytryptamine (5,7-DHT) dissolved in distilled water containing $1 \%$ ascorbic acid was injected. All indoleamines were creatine sulfates from Sigma. Four hours later, the eyes were enucleated under deep anesthesia. A small encircling cut was made around the ora serrata, and the eye cup was placed in $4 \%$ paraformaldehyde dissolved in $0.1 \mathrm{M}$ phosphate buffer ( $\mathrm{pH} 7.4$ ) for 1$2 \mathrm{hr}$ at room temperature. Following fixation the retina was dissected in $0.1 \mathrm{M}$ phosphate buffer (PB). Small radial incisions were made, and the retina was mounted in glycerol, coverslipped, and inspected microscopically under epifluorescence illumination.

In vitro uptake was performed on 10 retinas. The eyes were enucleated from deeply anesthetized animals and quickly opened by an encircling cut; the anterior chamber, lens, and vitreous were discarded. The eye cup was rinsed in cold physiological medium $\left(10^{\circ} \mathrm{C}\right)$ and transferred to the perfusion chamber containing the identical physiological medium (135 mM NaCl, $5 \mathrm{mM} \mathrm{KCl}, 1.24 \mathrm{mM} \mathrm{NaH}_{2} \mathrm{PO}_{4}, 1.3 \mathrm{mM} \mathrm{MgSO}_{4}, 2.4$ mM CaCl, $10 \mathrm{~mm}$ glucose, $0.1 \mathrm{~mm}$ ascorbic acid, and $20 \mathrm{~mm}$ HEPES, adjusted to $\mathrm{pH} 7.4$ with $\mathrm{NaOH}$ ) aerated with $95 \% \mathrm{O}_{2}, 5 \% \mathrm{CO}_{2}$ at $37^{\circ} \mathrm{C}$. Indoleamines were added at concentrations between $10^{-4}$ and $10^{-7} \mathrm{M}$, 
depending on the experiment, and the incubation allowed to proceed for $30 \mathrm{~min}$. The tissue was then rinsed briefly in cold medium $\left(10^{\circ} \mathrm{C}\right)$ as above and, in the case of antibody staining, fixed overnight at $4^{\circ} \mathrm{C}$ with $4 \%(\mathrm{wt} / \mathrm{vol})$ paraformaldehyde, $15 \%(\mathrm{vol} / \mathrm{vol})$ saturated picric acid in $0.1 \mathrm{M} \mathrm{PB}, \mathrm{pH} 7.5$. For formaldehyde-induced fluorescence, the eye cups were fixed at room temperature for $1-2 \mathrm{hr}$ in $4 \%$ paraformaldehyde dissolved in $0.1 \mathrm{M}$ PB.

Intracellular staining. In vivo uptake of 5,6-DHT and gentle fixation in $4 \%$ paraformaldehyde were performed as described above. Following fixation for $1 \mathrm{hr}$, the retinas were carefully dissected from the eye cups in $0.1 \mathrm{M} \mathrm{PB}$ (pH 7.4). They were divided into 3 parts, of which 2 were kept at $4^{\circ} \mathrm{C}$ for staining later. All further manipulations were performed at room temperature. The remaining section of retina was carefully floated onto a slide in $\mathrm{PB}(0.1 \mathrm{M}, \mathrm{pH} 7.4)$ and held in place by a Millipore filter with a hole slightly smaller than the piece of retina. The slide with the retina was immersed in a petri dish filled with $0.1 \mathrm{M}$ PB containing $2 \mathrm{~mm}$ ascorbic acid (Tauchi and Masland, 1984). The petri dish was placed onto a fixed-stage microscope (Zeiss ACM) for dye injection. Cell bodies of neurons that had taken up 5,6-DHT possessed a clearly visible yellow fluorescence. They were impaled and intracellularly stained microelectrodes filled with Lucifer yellow (Stewart, 1978, 1981) under direct visual control (for details, see Voigt, 1986).

After injection of several cells the retina was mounted on a slide and coverslipped with glycerol. Mosaic photographs of filled cells were taken on black-and-white film (Kodak Tri-X) and the cell shapes reconstructed by tracing the enlarged negatives.

Immunocytochemistry. Following in vivo or in vitro uptake of 5-HT, the eye cup was fixed in $4 \%$ paraformaldehyde, $15 \%$ saturated picric acid overnight at $4^{\circ} \mathrm{C}$, and thoroughly washed in $\mathrm{PB}$ to remove fixative. Retinas were immersed in $30 \%$ sucrose, frozen in liquid $\mathrm{N}_{2}$ and thawed at room temperature. All antibody dilutions and washes after each antibody treatment were done with PBS. The staining was carried out as follows. Tissues were treated with $3 \% \mathrm{H}_{2} \mathrm{O}_{2} / 10 \%$ methanol to destroy endogenous peroxidase, $1 \mathrm{~m}$ ethanolamine to react with any surplus fixative aldchyde groups, and $1 \%$ Triton X-100 to allow better penetration of antibodies into the retinal whole-mount. The material was then washed and transferred to primary anti-5-HT antibody (Immunonuclear Corporation) at a dilution of 1:200 containing normal goat serum ( $1 \%)$, BSA (5\%), and Triton-X-100 (0.5\%) for $3 \mathrm{~d}$. The second and third antibodies, goat anti-rabbit IgG or the FITC-labeled product, and PAP (Miles Scientific), were used at dilutions of 1:50 and 1:100, respectively, for $24 \mathrm{hr}$ and included normal goat serum and Triton as above. Peroxidase was visualized with the 3-3'-diaminobenzidine tetrahydrochloride (DAB) method. Tissues were first washed in $50 \mathrm{~mm}$ Tris- $\mathrm{HCl}$ buffer, $\mathrm{pH} 7.6$, and incubated in a solution of DAB $(0.05 \%)$ in the same buffer for $20 \mathrm{~min}$ and for a further $15 \mathrm{~min}$ in DAB solution containing hydrogen peroxide $(0.01 \%)$. The whole-mounts were either permanently mounted after dehydration and clearing in Permount or mounted in glycerol for initial obscrvation.

A control for the specific immunocytochemical staining is inherent in our study, as specific staining was obtained only after 5-HT preloading of the retina. However, as a further control, specific staining was completely abolished by incubating the primary antiserum with an excess of 5-HT-BSA conjugate, prepared according to the method of Ranadive and Sehon (1967).

Fluorescence microscopy. The final analysis of labeled and stained retinas was performed on coverslipped whole-mounts, which were mounted free floating in glycerol with the ganglion side facing up. Following uptake of 5,6-DHT and paraformaldehyde fixation, labeled cell bodies showed a bright yellow fluorescence (filter combination: Zeiss, BP 450-490, FT 510, LP 520). The fluorescence of 5,7-DHT was blue and best visible, with the following filter combination: BP 340-380, FT 425, and LP 435. Lucifer ycllow-filled cclls and 5,6-DHT-labeled cell bodies were both equally visible when BP 400-440, FT 460, and LP 470 were used. No correction for shrinkage of the tissue was applied.

\section{Results}

Uptake of indoleamines by neurons of the cat retina

After injection of $20 \mu \mathrm{g} \mathrm{5-HT}$ into the vitreous of a cat eye, followed by immunocytochemistry with an antibody directed against 5-HT, many cell bodies in the inner nuclear layer and in the ganglion cell layer were found to be labeled. Injection of 5,6-DHT, followed by paraformaldehyde fixation, revealed a bright yellow fluorescence in many cell bodies in both the inner nuclear layer and the ganglion cell layer. Since 5-HT-accumulating and 5,6-DHT-labeled neurons appeared to belong to an identical cell population, we performed an experiment to test the validity of this apparent homogeneity. For in vivo uptake, 5-HT $(20 \mu \mathrm{g})$ and 5,6-DHT $(20 \mu \mathrm{g})$ were injected into the same eye. The retina was fixed and the formaldehyde-induced fluorescence first documented in detail. A small field of such a retina is shown in Figure $1 A$; the branched blood vessel was used as an orientation point. The micrograph was taken with the focus on the ganglion cell layer. Many cells of differing sizes and labeling intensities can be seen. A population of small cell bodies with bright fluorescence is evident. The same retina was then stained with the anti-5-HT antibody followed by a FITC-coupled sccond antibody. The retinal ficld was found again using the orientation point in the whole-mount and is shown in Figure $1 B$. It is clear that the same cells shown in Figure $1 A$ are again labeled and that no additional cells are fluorescent. The labeling is crisper and brighter than the formaldehyde-induced fluorescence. One might argue that this fluorescence is not caused by the FITC-coupled antibody but by the original formaldehyde fluorescence. This is unlikely because in control experiments, where only 5,6-DHT was used for in vivo uptake, the anti-5HT antibody showed almost no cross-reactive structures in the retina, and the initial formaldehyde-induced fluorescence faded completely during immunocytochemical processing. A final test for the labeling of cells by the anti-5-HT antibody is shown in Figure $1 C$. The same retina was incubated once more for immunocytochemistry to show labeled cells using the PAP method. Despite the higher background, the identical cells as those in Figure $1, A$ and $B$, are labeled. This experiment formally proves that 5,6-DHT and 5-HT are both accumulated by the same neurons.

As can be observed in Figure 1, cell body sizes and labeling intensities were nonuniform. A group of small cell bodies was labeled most intensely, some medium-sized cell bodies showed moderate intensity, and the relatively large cell bodies (Fig. 1, arrows) were only weakly labeled.

\section{Morphological identification of indoleamine-accumulating neurons}

Uptake of 5,6-DHT alone labeled the cell bodies relatively strongly and dendritic network weakly in the inner plexiform layer; however, this staining did not elucidate the shape of individual cells. To reveal the dendritic morphology of the cells, neurons showing 5,6-DHT formaldehyde-induced fluorescence were injected under visual control with an LY-filled microelectrode. Because both the cell bodies and the electrode tip were visible with the same filter combination under epifluorescence, it was possible to impale the cells and fill them (Tauchi and Masland, 1984; Vaney, 1984).

A comparative diagram of the 3 cell types injected following uptake of 5,6-DHT is shown in Figure 2. The cell type in the center, which has an extremely sparsely branched dendritic tree, was filled whenever one of the small brightly fluorescent cell bodies (Fig. 1) was impaled with the microelectrode. Cells of the shape illustrated in Figure 2 (lower right) were stained when Lucifer yellow was injected into medium-sized perikarya. The largest cell bodies labeled by 5,6-DHT (Fig. 1, arrows) were always ganglion cells, as judged from the filled axon, of a distinct morphology. Such a ganglion cell is shown in Figure 2 (upper left). 

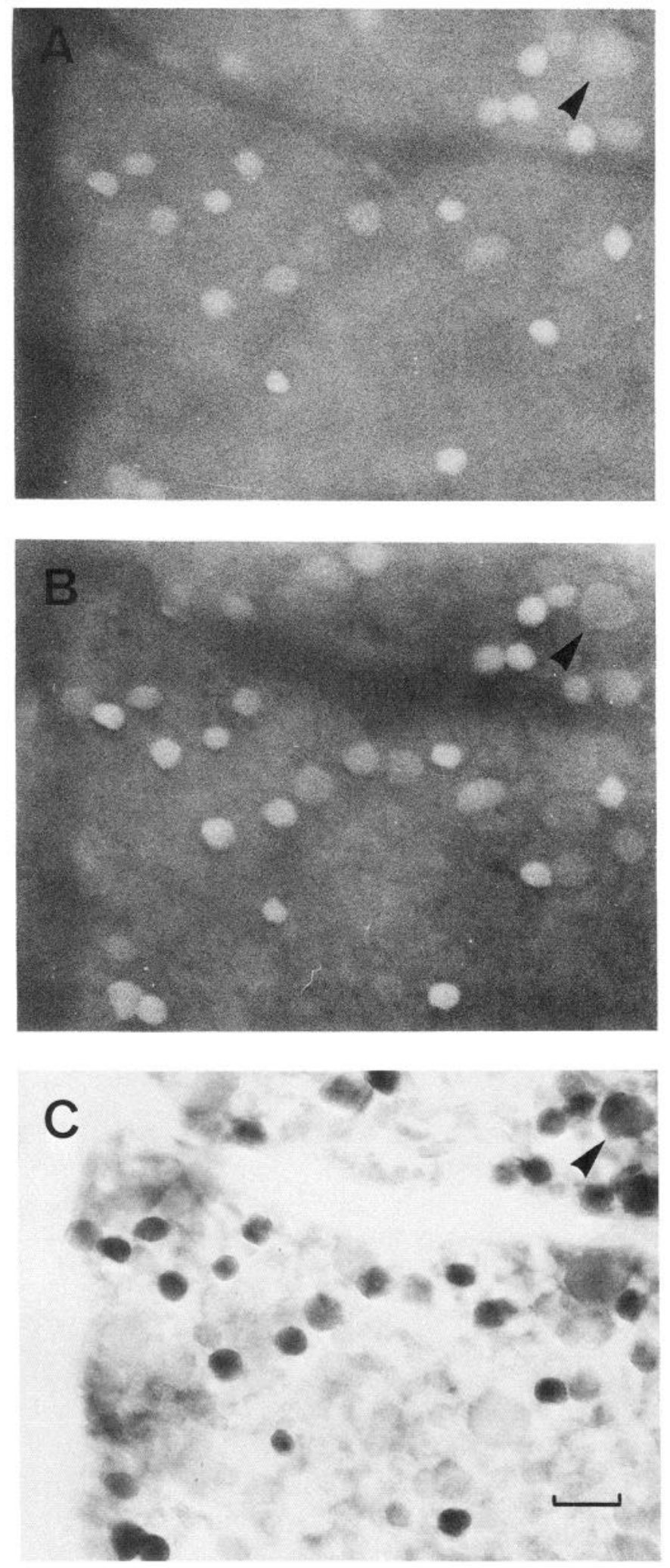

Figure 1. Neurons in a cat retinal whole-mount labeled by uptake of indoleamines. All 3 micrographs show the same field of retina with the focus at the ganglion cell layer. Following injection of $20 \mu \mathrm{g} \mathrm{5,6-DHT}$ and $20 \mu \mathrm{g} 5-\mathrm{HT}$, three different methods to demonstrate indoleamine uptake were applied. $A$, Micrograph showing the formaldehyde-induced fluorescence of cell bodies that have taken up 5,6-DHT. $B$, Fluorescence micrograph taken after the retina was stained by immunohistochemistry. The first antibody was directed against 5-HT, and the second
The 3 types of neurons are described in more detail below. Descriptive terms are used to avoid confusion in the classification of these neurons. In the discussion at the end of the paper, a comparison is made with Golgi-stained cells (Kolb et al., 1981).

\section{Sparsely branched wide-field amacrine cells}

The class of small cell bodies in Figure 1 was always more intensely labeled following uptake of any of the indoleamines. These neurons were found both in the inner nuclear layer and in the ganglion cell layer. Ninety-five of these cells were injected, and all of them showed the same general morphology, regardless of whether the cell body was placed in the ganglion cell layer or in the inner nuclear layer. The small cell bodies $(8.2 \pm 0.8$ $\mu \mathrm{m})$ sent out 4-8 very thin dendrites, which possessed hardly any side branches but extended for up to $2 \mathrm{~mm}$. Three of these cells are shown in Figure 3 and illustrate their typical loose branching pattern. Only 4-8 dendrites constituted the dendritic field. The micrograph in Figure $4 A$ illustrates the delicate branching of 3 cells filled in a small area of retina. Small varicosities can be observed at regular distances along the thin processes. An axon was never observed emerging from any of these cells, and we therefore assume that all are amacrine cells, of which some are displaced into the ganglion cell layer. Many cell bodies in the ganglion cell layer, which measured approximately $8 \mu \mathrm{m}$, survived transection of the optic nerve (unpublished observation) and are quite likely displaced amacrine cells (Hughes and Wieniawa-Narkiewicz, 1980).

The stratification level of dendritic branches in the inner plexiform layer (IPL) is of major functional significance. The Onand Off-channels have been found to occupy different bands in the IPL (Nelson et al., 1978). We estimated the stratification level of the injected cells by taking readings of the depth using the scale on the fine focus of the microscope. The labeled cell bodies in the amacrine and ganglion cell layer were used as a reference plane. The stratification level of 95 injected cells is shown in a histogram (Fig. 5). Most of the dendrites ramify in the outer half of the IPL, with the mean stratification level being $58.4 \pm 11 \%$ of the total extent of the IPL. This level is approximately at the borderline between the Off- and On-sublamina of ganglion cell dendrites (Nelson et al, 1978; Wässle et al., 1981). The photomicrograph in Figure $4 A$ also shows that these cells are narrowly stratified and, in addition, the dendrites of cells in the amacrine layer and those of cells in the ganglion cell layer meet in the same stratum.

The dendritic branching pattern of the cells is rather strange and one might question the functional significance of such a sparsely branched cell. We feel confident that this appearance is not the result of understaining because we could fill even smaller branches of other cells (see Fig. 7) and never observed short, small side branches on those dendrites that would indicate shortcomings of the filling technique. Whether individual branches might be even longer than the observed $2 \mathrm{~mm}$ cannot be stated at present as the dendrites tend to be extremely fine at their tips and may be beyond the resolution of the light microscope. It is pointless to define a dendritic field of such a

antibody was FITC coupled. $C$, Micrograph showing the retina after
further immunohistochemical staining. The first antibody directed against 5 -HT was detected by the PAP method. Scale bar, $20 \mu \mathrm{m}$. 


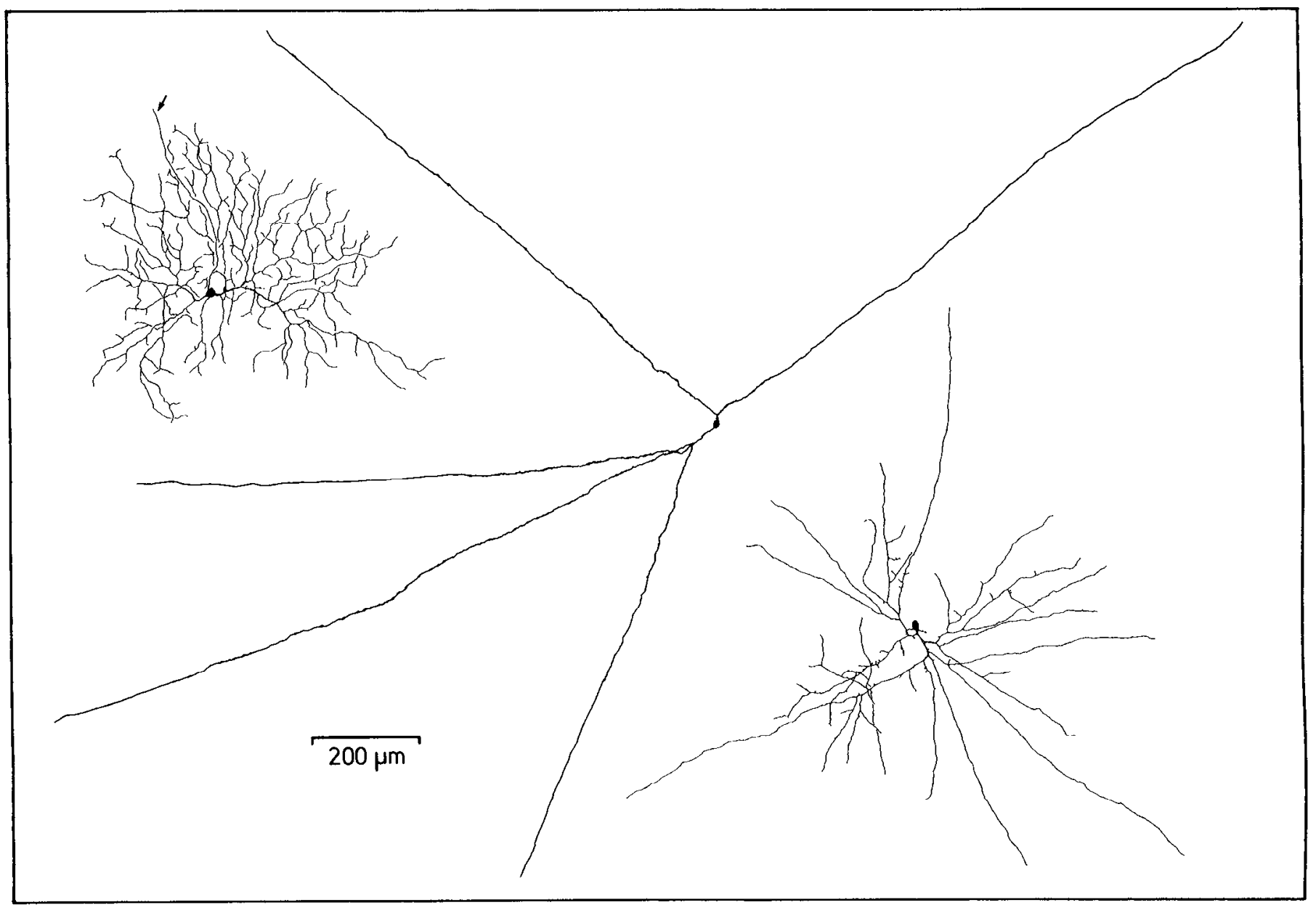

Figure 2. Comparative drawings of 3 Lucifer yellow-injected cells, which were prelabeled by uptake of 5,6-DHT. All 3 cells were from midperipheral retina and had their cell bodies in the ganglion cell layer. The cell in the center had a brightly labeled small cell body (7.5 $\mu \mathrm{m})$ and extremely fine, sparsely branched dendrites with regularly spaced varicosities. The cell type illustrated in the lower-right corner had a larger cell body (10 $\mu \mathrm{m})$, which was less intensely labeled. Small spinelike processes were observed on the dendrites. The cell in the upper-left corner is a ganglion cell (the arrow points to the axon). The cell body $(15 \mu \mathrm{m})$ was only weakly labeled. For the sake of reproduction, the processes of all 3 cells are drawn thicker than they actually were.

cell because the dendrites of individual cells do not cover a defined area. However, to judge the functional impact of these cells, an estimate of the density of their dendritic network was obtained. The total length of dendrites of an individual cell such as in Figure 2 was measured to be $6 \mathrm{~mm}$. In the vicinity, the density of small brightly labeled amacrine cells (5,6-DHT formaldchyde fluorescence) was cstimatcd at $500 / \mathrm{mm}^{2}$. Thereforc, in each square millimeter of retina these cells would possess a cumulative dendritic length of $3 \mathrm{~m}$, which could be calculated to provide a dendritic network with a $0.7 \mu \mathrm{m}$ spacing. This shows that despite the loose branching pattern, the high density of cells and their long dendrites make an efficient network feasible.

\section{Spiny amacrine cells}

Injection of medium-sized, less intensely labeled cell bodies (see Fig. 1) revealed cells with a branching pattern different from that described above. This type of Lucifer yellow-injected cell is shown in Figure $4 B$. Compared with Figure $4 A$, the thicker primary dendrites and denser dendritic branching pattern are apparent. Closer inspection of the processes, such as the verti- cally descending one shown in Figure $4 B$, revealed small spinelike processes. A drawing of a representative cell of this type is shown in Figure 2 and compared with the other injected cells. Their branching pattern is further illustrated in Figure 6. Altogether 15 cells were injected, and again their cell bodies were found both in the inner nuclear layer and in the ganglion cell layer. The 3 cells in Figure $6 A$ were from the amacrine layer and the 3 in Figure $6 B$ from the ganglion cell layer, and there is no apparent difference in their dendritic branching pattern. However, the stratification level of their dendrites was clearly different. Cells in the amacrine layer were observed to form a dendritic plexus close to the inner nuclear layer, whereas the dendrites of the cells in the ganglion cell layer kept their branches close to that layer. No axons were filled, and hence both populations were presumed to be amacrine cells. The overall "Gestalt" of the cells is rather irregular (Fig. $6 B$ ), with some very long fine branches. It remains open whether this illustrates the limitations of the filling technique or the true profile of the cell. Overall we are less confident about grouping these amacrines in a homogeneous class. Considering the limited number injected, and their rather high density in the inner nuclear layer, 
Figure 3. Drawings of 3 cells injected with Lucifer yellow, after their cell bodies were labeled by uptake of 5,6-DHT. The cells are from midperipheral retina and had small brightly labeled cell bodies. The cell to the left had its perikaryon in the inner nuclear layer, the other 2 in the ganglion cell layer. The cells are assembled randomly and are from 2 different cats.

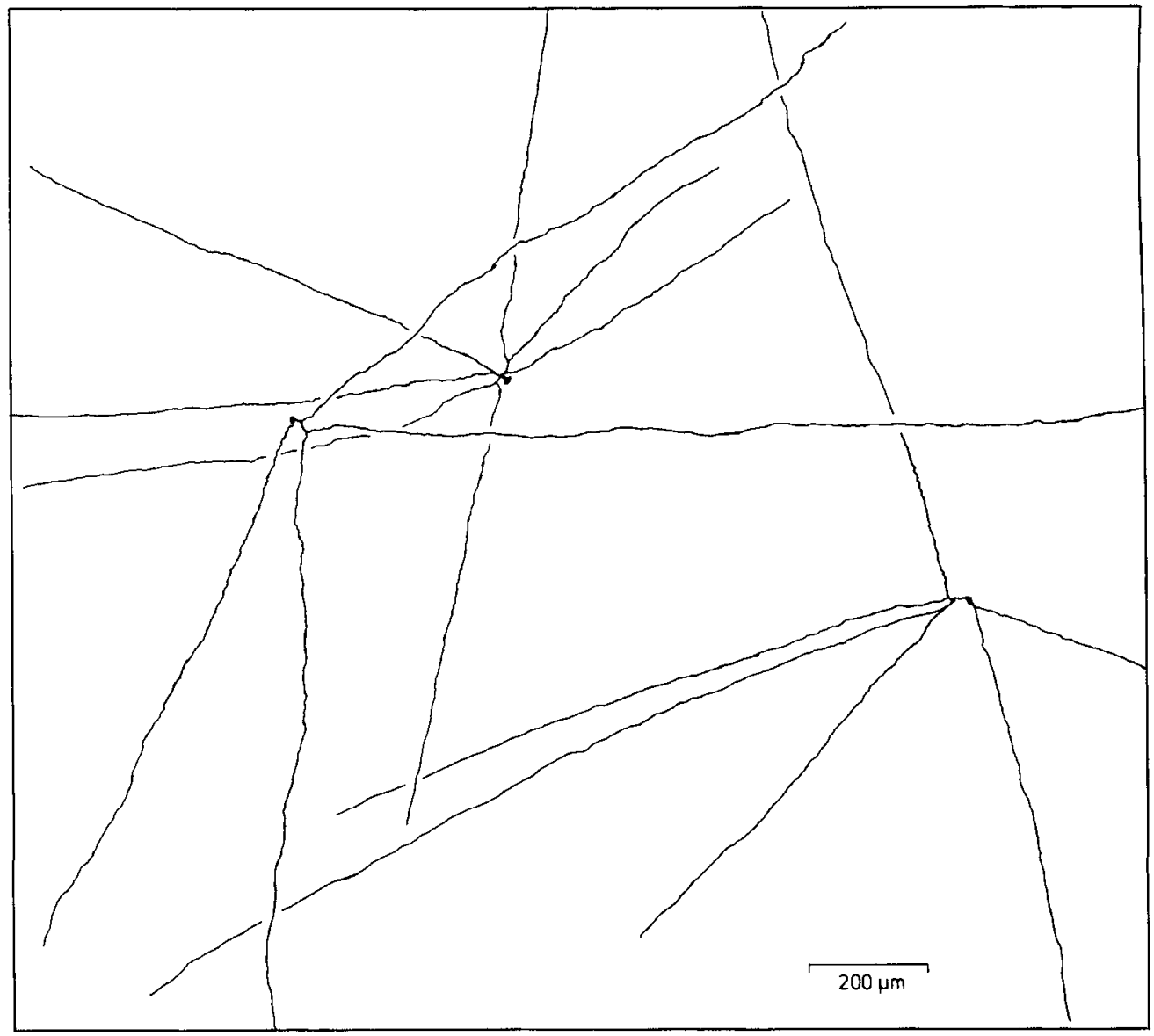

it might well be that the medium-sized amacrine cells that take up 5,6-DHT are composed of more than the described class of spiny amacrines.

\section{Further amacrine cell types injected}

Since the uptake systems for indoleamines and catecholamines seem to overlap broadly with regard to their specificities, one could argue that catecholamine-accumulating neurons might be included in the cell types defined here. In some additional experiments to be described in detail elsewhere, the Falck-Hillarp histofluorescence technique (4\% paraformaldehyde, $0.5 \% \mathrm{glu}$ taraldehyde) revealed an amacrine cell with a large cell body $(15 \mu \mathrm{m})$ possessing a blue fluorescence. The density of these cells was low $\left(<20\right.$ cells $\left./ \mathrm{mm}^{2}\right)$ and the dendritic plexus close to the IPL had characteristic ring endings (Törk and Stone, 1979). The same cell type has previously been shown to accumulate ${ }^{3} \mathrm{H}$ dopamine (Pourcho, 1982) and possesses tyrosine hydroxylaselike immunoreactivity (Oyster et al., 1985). We injected these cell bodies with Lucifer yellow, and the dendritic branching pattern found was different from the indoleamine-accumulating amacrine cells described above. These putative dopaminergic cell bodies were visible only when glutaraldehyde had been added to the fixative; with paraformaldehyde fixation alone, as in the present study, they were not detectable. Therefore, we feel confident that the indoleamine-accumulating amacrines described here do not include the catecholaminergic amacrines of the cat retina.

Rabbit indolcamine-accumulating amacrinc cclls (Sandell and Masland, 1986; Vaney, 1986) have a strikingly different ap- pearance from that described here for the cat. Both rabbit studies, however, used 5,7-DHT for uptake, rather than the 5,6DHT used in the present study, followed by Lucifer yellow filling of labeled structures. We thus performed a control experiment with $5,7-\mathrm{DHT}$ injection $(20 \mu \mathrm{g})$ into the cat eye to check whether the difference in amacrine cell populations labeled by indoleamines in rabbit and cat was real or due to differing uptake characteristics of 5,6- and 5,7-DHT. The labeling of cell bodies showed a blue fluorescence, but the general pattern was the same as in Figure 1 and the 16 injected cells had the same appearance as those illustrated in Figure 2.

In a further experiment we injected a cat eye with twice the amount of 5,6-DHT $(40 \mu \mathrm{g})$ to check for any other cells that may accumulate indoleamines at higher concentrations. Apart from the cells already mentioned, a large number of additional cell bodies, including $\alpha$-ganglion cells, showed fluorescence. We systematically injected these other cells with Lucifer yellow and on several occasions filled amacrine cells of the types illustrated in Figure 7. Their dendritic branching pattern is similar to that of indoleamine-accumulating cells described for rabbit retina. Thus, although in the cat retina, cells of a comparable shape to the indoleamine-accumulating cells of rabbit exist, they do not take up indoleamines at the concentrations normally injected here $(20 \mu \mathrm{g})$.

\section{Indoleamine-accumulating ganglion cells}

A population of weakly labeled cells could be detected in the ganglion cell layer only, with cell body sizes of approximately $16 \mu \mathrm{m}$. One such cell body is noted in Figure 1, and a population 

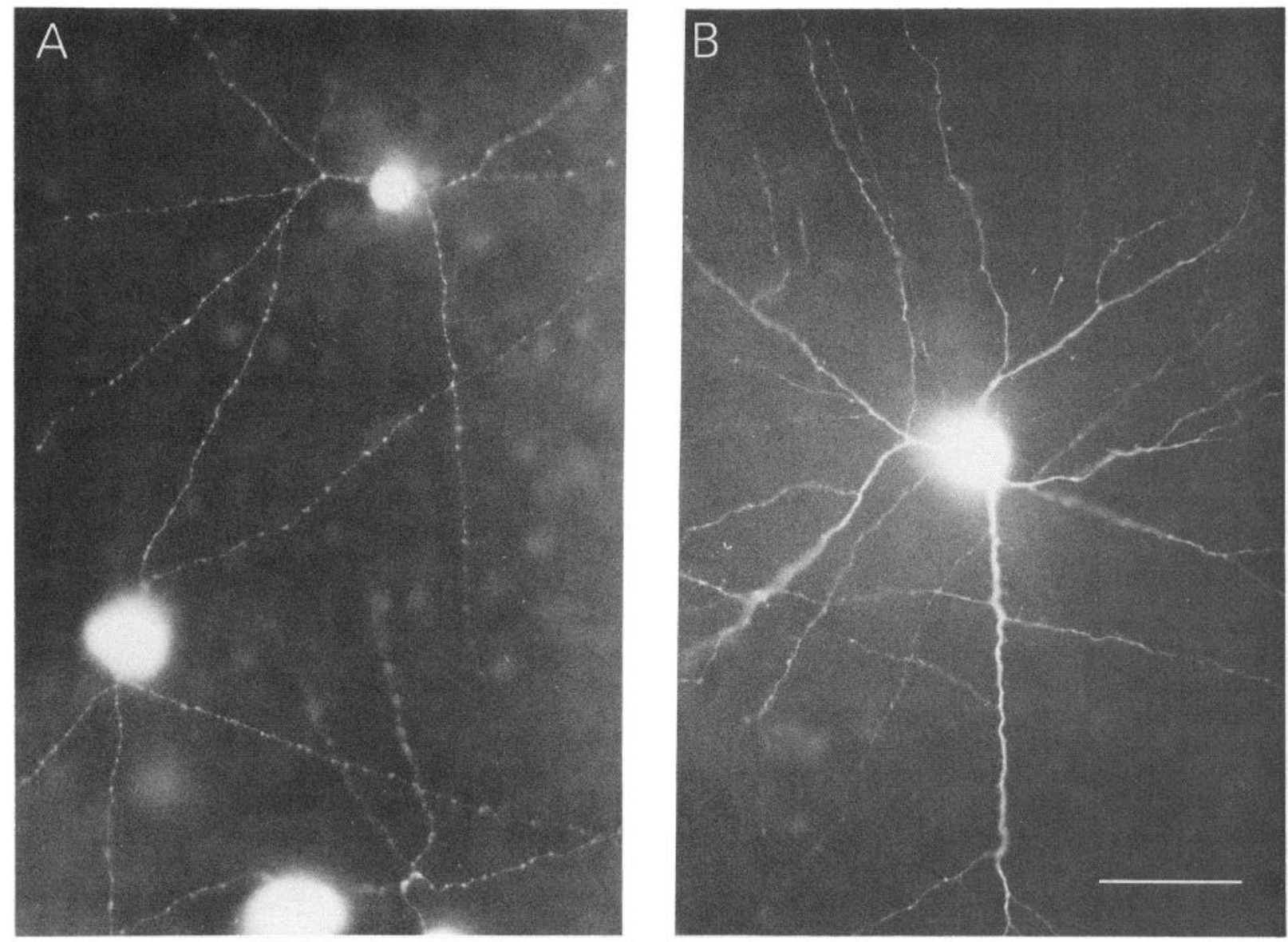

Figure 4. Fluorescence micrographs of Lucifer yellow-injected cells from a whole-mount of the cat retina. The cells were prelabeled by uptake of 5,6-DHT. A, Micrograph with the focus in the IPL illustrating the delicate dendritic branching pattern of 3 cells that have a small brightly labeled cell body. The varicosities give the dendrites a beaded appearance. The cell bodies are out of focus and, because of photographic irradiation, their size cannot be judged here. The faint labeling of other cell bodies in the inner nuclear layer by uptake of 5,6-DHT can also be detected. The cell at the top had its cell body in the amacrine layer; the 2 cells at the bottom had their cell bodies in the ganglion cell layer. $B$, Lucifer yellow-injected cell with a slightly larger, less intensely labeled cell body. The dendrites are thicker, more densely branched and have spinelike appendices. Scale bar, $50 \mu \mathrm{m}$.

is shown at low magnification in Figure $8 A$. Their density (Fig. $8 A$ ) was much lower than that of the smaller cell bodies, and it was possible to fill several cells of this type with the microelectrode in a restricted field of retina. Two immediate neighbors and their dendrites are illustrated in Figure $8 B$. The dendritic trees cover the field evenly, and, in the zone of overlap, dendrites of the 2 cells seem to "respect" each other's territories. Both cells have a similar branching pattern and are narrowly stratified in the Off-sublamina of the IPL. The 2 cells, as well as a third neighbor, are illustrated in Figure 9. All 3 cells had an axon ascending into the optic nerve fiber layer; hence they are ganglion cells. Incidentally, in the same area an unlabeled $\beta$-ganglion cell was filled with Lucifer yellow through its axon and is illustrated for comparison (Fig. 9, upper left). It is clear that the labeled cells are not $\beta$-ganglion cells; their dendritic fields are larger and less densely branched, and their cell body size (16 \pm $1.7 \mu \mathrm{m})$ is smaller than that of injected $\beta$-cells $(21 \pm 1.3 \mu \mathrm{m})$. Twelve ganglion cells were filled, and all had comparable dendritic branching patterns. Only 2 labeled and filled cells had their dendrites in the On-sublamina; the other 10 cells had a stratification level in the Off-sublamina of the IPL. It is quite likely that they constitute a single morphological type of ganglion cell, which comprises an On- and Off-subpopulation (Nel- son et al., 1978; Wässle et al., 1981). Altogether 9 ganglion cells were labeled in the patch of retina illustrated in Figure 9, and their density was estimated to be $8 / \mathrm{mm}^{2}$. From the product of dendritic field size and density, the coverage factor was calculated to be between 2 and 3; hence both an On- and an Offsubpopulation could effectively cover this field with their dendrites. In a comparable manner, a second patch of retina close to the central area was investigated. The density of indoleamineaccumulating ganglion cells at approximately $1 \mathrm{~mm}$ eccentricity was 65 cells $/ \mathrm{mm}^{2}$, the dendritic fields of injected cells were 300 $\mu \mathrm{m}$ in diameter, and the calculated coverage, 4.9. Apparently this type of indoleamine-accumulating ganglion cell shows an increase in density toward the central area and a decrease of dendritic field size. Dendritic field size, density, coverage, and retinal topography of this ganglion cell type is comparable to the $\alpha$-cell system; morphologically, however, they represent a different ganglion cell class not described in detail before.

\section{Quantification of indoleamine uptake in the cat retina}

Injections of substances into the vitreous of the eye produce a concentration gradient at the level of the retina. Close to the injection site a higher concentration will be available relative to more distant regions. It was noted in the present experiments 


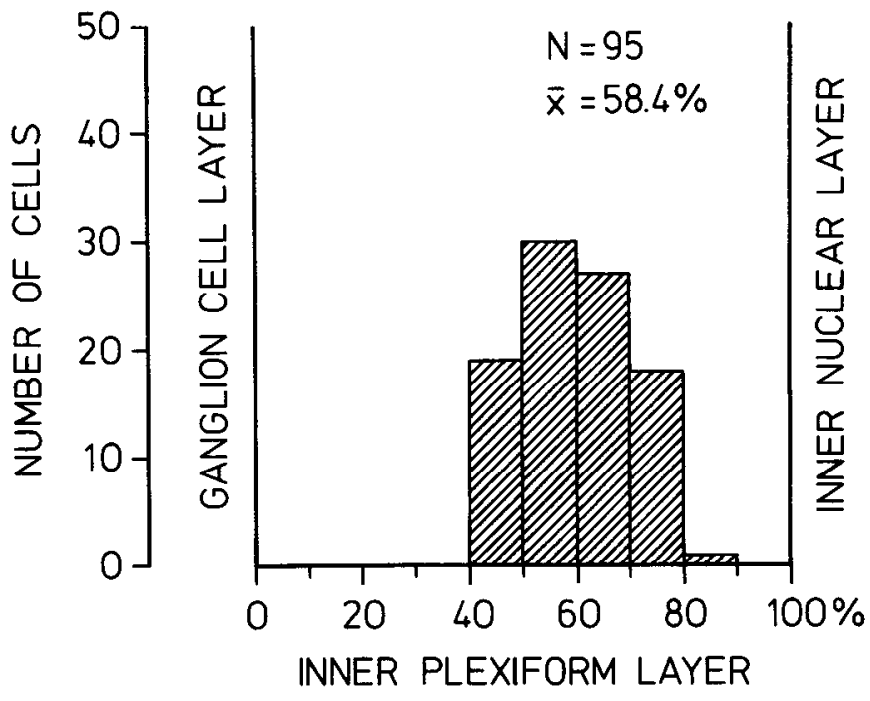

Figure 5. Histogram indicating the dendritic branching level of 5-HT accumulating neurons in the inner plexiform layer. All 95 cells were of the type illustrated in Figure 4. The abscissa, expressed as the percentage of total inner plexiform layer thickness, indicates the depth where branching was observed. Zero coincides with the perikarya labeled in the ganglion cell layer; $100 \%$ is at the level of labeled amacrine cells in the inner nuclear level. The ordinate shows the number of cells found to branch at a particular depth. that the uptake of injected indoleamines was not homogeneous over the retina. In peripheral retina only the smallest amacrine cells were labeled. Closer to the injection sites, medium-sized amacrine cells and ganglion cells became visible. Near the injection sites the concentration of the injected indoleamine was apparently so high that uptake into Müller cell pedicles and all ganglion cells was occasionally observed. Assuming a volume of $2 \mathrm{ml}$ for the vitreous of a cat eye (Vakkur and Bishop, 1963), the injected amount of $20 \mu \mathrm{g} 5,6-\mathrm{DHT}$ would produce a concentration of $2.5 \times 10^{-5} \mathrm{M}$ when homogeneously distributed.

In vitro uptake studies of the isolated eye cup were performed (as described in Materials and Methods) to avoid the problem of concentration gradients in the intact eye. For 5,6-DHT formaldehyde-induced fluorescence, the minimum concentration required to detect labeled cells was $10^{-5} \mathrm{M}$. Only the small amacrine cell population was labeled at this concentration. When uptake of 5-HT was studied by immunocytochemistry, the lowest concentration required was $10^{-7} \mathrm{M}$, and only the small amacrine cells were labeled. It is not possible to say with certainty that this difference in the concentration threshold reflects different uptake capacities for 5-HT and 5,6-DHT. However, it probably shows the superior sensitivity of immunocytochemistry compared with formaldehyde-induced fluorescence. Figure 1 supports this speculation, because cells that were barely detectable in the formaldehyde-induced fluorescence (Fig. 1A)
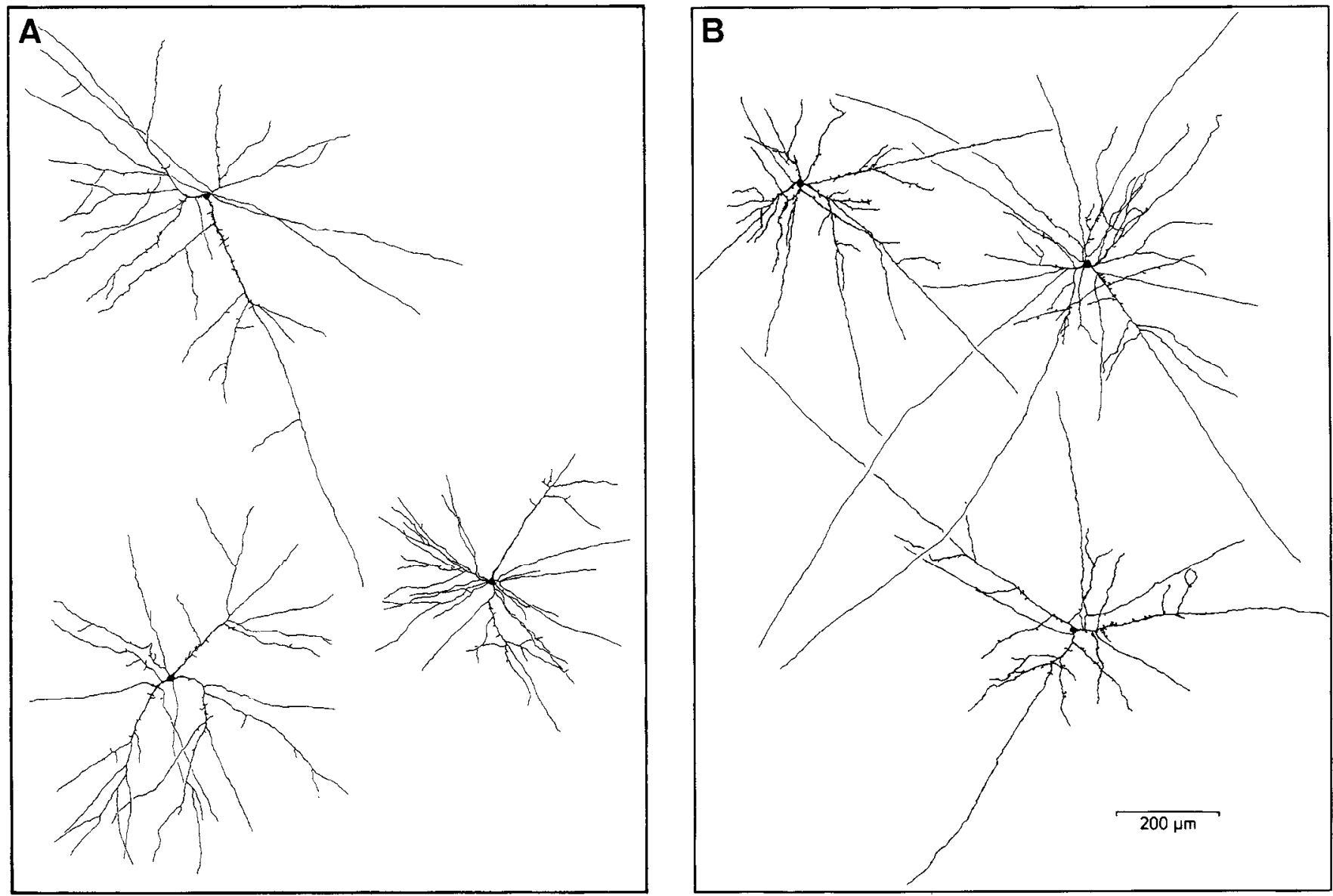

Figure 6. Drawings of 6 cells injected with Lucifer yellow after uptake of 5,6-DHT. The cells had moderately labeled perikarya of approximately 9-12 $\mu \mathrm{m}$ size. The cell bodies in $A$ were in the amacrine cell layer; those in $B$ were displaced to the ganglion cell layer. A micrograph of the cell drawn in the upper-right corner of $B$ is shown in Figure $4 B$ and illustrates at higher magnification the central part of this cell and the spines on some dendrites. 
showed a crisp and definite label when immunocytochemistry was applied (Fig. 1, B, C). The antibody directed against 5-HT was not sensitive for 5,6-DHT, and hence a direct comparison could not be performed.

When the concentration of 5,6-DHT during in vitro uptake was raised to $10^{-4} \mathrm{M}$, a homogeneous labeling of the 3 described cell types was achieved throughout the retina with formaldehyde-induced fluorescence, and quantitative evaluation became possible. Figure 10 shows the density of labeled cells along the vertical meridian through the central area. The total number of labeled cells peaked at approximately 4500 cells $/ \mathrm{mm}^{2}$ in the central area; the minimum count of 800 cells $/ \mathrm{mm}^{2}$ was found in upper peripheral retina. On average, $77 \%$ of the fluorescent cells were found in the amacrine cell layer and $23 \%$ in the ganglion cell layer. Only the small brightly labeled amacrine cells could be separately counted, and they were found to constitute $70 \%$ of the labeled cells in the ganglion cell layer and approximately $50 \%$ of those in the amacrine layer. Their density also increased from the peripheral to central retina (lower 2 graphs in Fig. 10).

\section{Proportion of indoleamine-accumulating amacrine cells}

Figure 11 shows the distribution of immunolabeled neurons of both the ganglion cell layer and the inner nuclear layer in a small field of peripheral retina following injection of $20 \mu \mathrm{g} 5-\mathrm{HT}$ into the vitreous. The field selected was in an area of homogeneous labeling. Differences in cell body sizes and labeling intensities are well illustrated in this micrograph. Using Nomarski optics the unlabeled neurons can also be detected and the fraction of 5-HT accumulating cells can be estimated. The micrograph in Figure $11 B$ looks slightly patchy because labeled cells in the ganglion cell layer (Fig. 11 A) cause shadows. This, together with the lack of color information, makes counting from the micrograph difficult. When the evaluation was performed on the microscope, $8.3 \%$ of all amacrine cells in Figure $11 B$ were found to take up 5-HT. Taking into account displaced amacrines too, approximately $10 \%$ of all amacrine cells in peripheral retina were labeled by uptake of indoleamines.

\section{Discussion}

\section{Is 5-HT a transmitter in the cat retina?}

Following in vitro uptake of 5-HT at a concentration of $10^{-7} \mathrm{M}$, immunocytochemistry revealed labeled amacrine cells in the cat retina. Several attempts to detect endogenous 5-HT using the same technique failed. No 5-HT was detected immunocytochemically in the cat retina even after treatment to cnhancc endogenous levels by injection of tryptophan and monoamine oxidase inhibitors. Similar unsuccessful attempts to localize endogenous 5 -HT by immunocytochemistry in other mammals have been reported (Osborne et al., 1981; Tornquist et al., 1983). These negative results are in contrast to biochemical studies (high-pressure liquid chromatography), which have shown the presence of very small amounts of 5-HT in mammalian retinas (Osborne et al., 1982; Tornquist et al., 1983). There is good evidence (Redburn, 1985) for a high-affinity uptake system of 5 -HT in mammalian retinas $\left(K_{T} 0.06-0.9 \mu \mathrm{M}\right)$, and the abovementioned uptake threshold of $10^{-7} \mathrm{M}$ is of the right order for a specific uptake system in the cat.

When applied iontophoretically in the cat retina, 5-HT has a powerful effect upon the discharge rate of cat retinal ganglion cells (Thier and Wässle, 1984). Finally ${ }^{3} \mathrm{H}-5-\mathrm{HT}$ taken up into

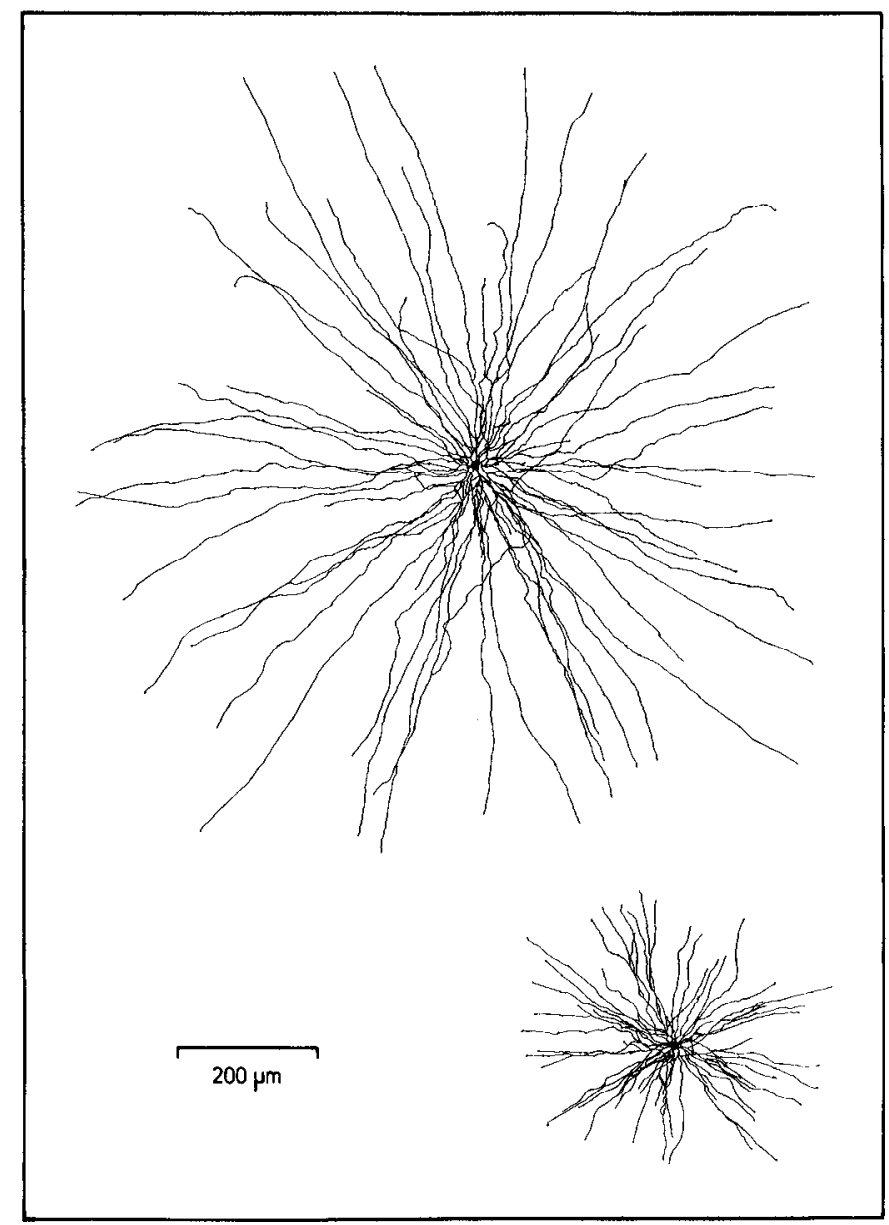

Figure 7. Two cells injected with Lucifer yellow labeled by indoleamine uptake only when twice the $5,6-\mathrm{DHT}$ dose $(40 \mu \mathrm{g})$ was injected. This dose labeled a variety of cells including alpha-ganglion cells. The 2 cells shown have extremely delicate branches with regularly spaced varicosities. Their general appearance is comparable to the indoleamineaccumulating amacrine cells of the rabbit retina (Sandell and Masland, 1986; Vaney, 1986).

mammalian retina can be released by depolarizing levels of potassium (Thomas and Redburn, 1979; Osborne, 1980), and there is good evidence for the presence of 5-HT binding sites (Mitchell and Redburn, 1985). Thus, 5-HT seems to meet most of the necessary criteria of a neurotransmitter in the mammalian retina, except that its endogenous levels are very low.

Only the amacrine type illustrated in Figure 3, having the smallest cell body and sparsely branched dendritic field, was found to take up exogenous 5-HT at a concentration of at least $10^{-7} \mathrm{M}$. As evidenced by the brighter induced fluorescence or darker staining with PAP immunocytochemistry, these cells also accumulated more indoleamines in their cell bodies than the amacrines illustrated in Figure 6 and the ganglion cells shown in Figures 8 and 9. Hence, if the cat retina utilizes 5-HT as a transmitter, we suggest that these are the most likely neurons to do so.

The spiny amacrine cells (Fig. 6) required a higher concentration of exogenous indoleamine to become labeled, and it is questionable whether they accumulate $5-\mathrm{HT}$ by a high-affinity uptake system. It is possible that they use a transmitter different from 5-H' and are labeled by low-affinity uptake. An amacrine cell of comparable morphology has been described as accu- 

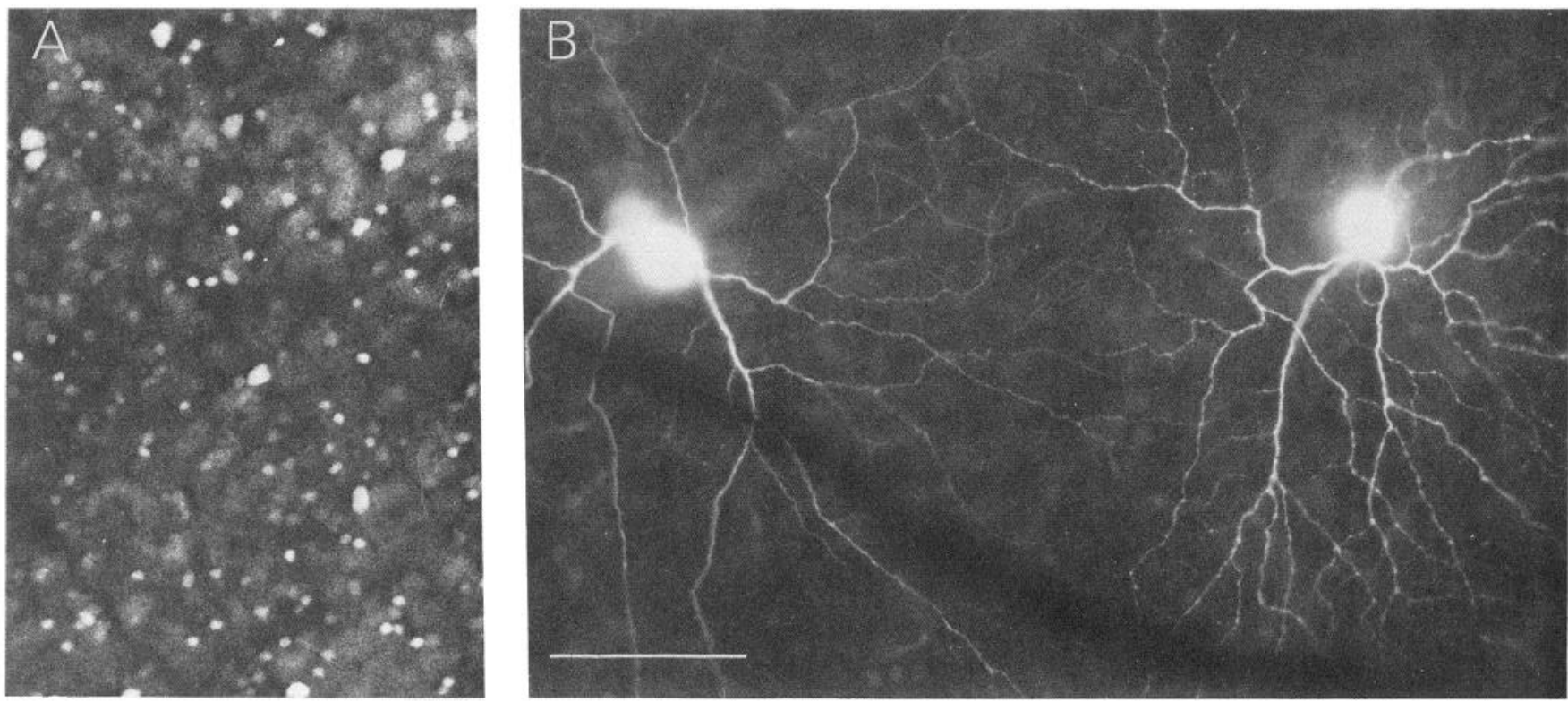

Figure 8. Fluorescence micrographs showing the labeling of ganglion cells by uptake of 5,6-DHT. $A$, Low-power micrograph focused on the ganglion cell layer of a retinal whole-mount. It shows the formaldehyde-induced fluorescence following 5,6-DHT uptake. Ten cell bodies of labeled ganglion cells can be recognized because of their larger sizes. They are regularly distributed with the exception of a twin close to the upper-left corner. The field is from the central retina. $B, 2$ Lucifer yellow-injected ganglion cells from peripheral retina. The dendrites of these 2 neighboring cells stratify at the same level (the Off-sublamina) and not much overlap of the dendritic fields is observed. A drawing of the 2 cells is shown in Figure 9. Scale, $133 \mu \mathrm{m}(A)$ and $100 \mu \mathrm{m}(B)$.

mulating the GABA agonist ${ }^{3} \mathrm{H}$-muscimol (Pourcho and Goebel, 1983). Recently, amacrine cells in rabbit retina were demonstrated to take up exogenous 5-HT and to possess glutamic acid decarboxylase-like immunoreactivity (Osborne and Beaton, 1986). It is probable, therefore, that some of the GABAergic neurons in cat retina may also take up indoleamines.

Finally, the ganglion cells illustrated in Figures 8 and 9 required the highest concentration for uptake and showed the weakest label. 5-HT is an unlikely transmitter candidate for these cells since the use of slightly higher concentrations non- specifically labeled all ganglion cells. If they were all serotoninergic, 5-HT should be present in all optic tract terminals in the geniculate, but this seems not to be the case (unpublished observations).

\section{Morphological types of indoleamine-accumulating amacrine cells}

Leaving the transmitter discussion aside, uptake of 5,6-DHT in combination with intracellular staining proved to be a reliable marker of at least 3 types of neurons in the cat retina. Using

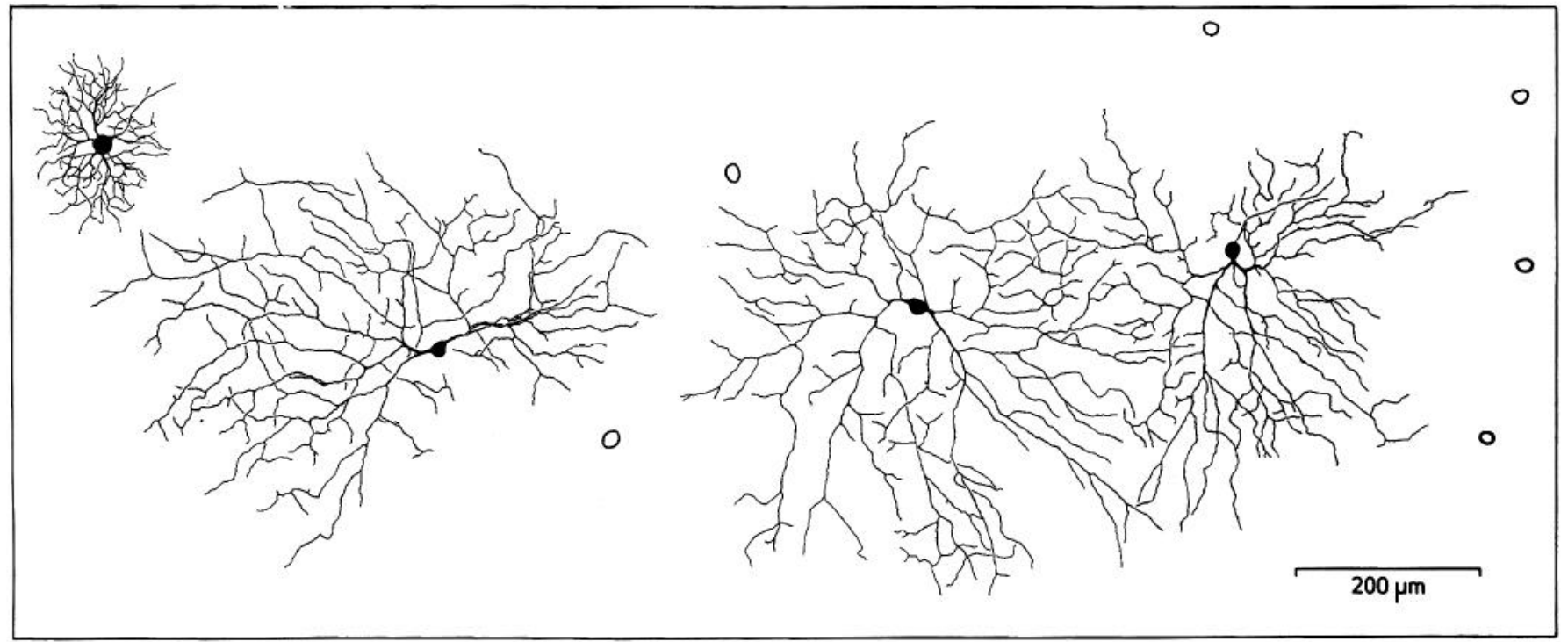

Figure 9. Drawings of labeled and Lucifer yellow-filled ganglion cells in a small field of midperipheral cat retina. The open circles indicate ganglion cell bodies that had taken up 5,6-DHT. Three of those cells were injected with the microelectrode and their dendrites filled. They have identical branching patterns and quite likely constitute a single morphological type. For comparison, a beta-cell filled through its axon is shown in the upper left. It is apparent that the other 3 cells are not beta-cells, since they have a smaller cell body and a wider, less densely branched dendritic tree. 


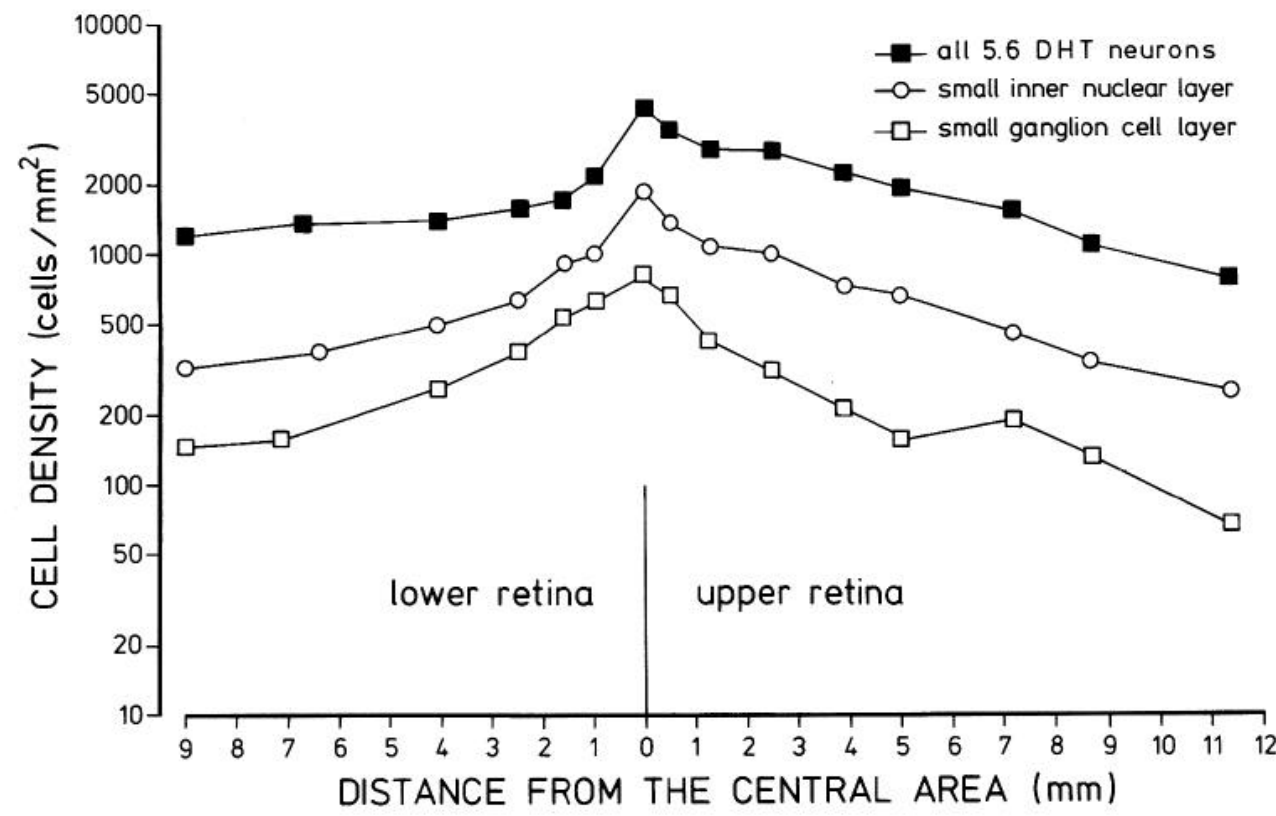

Figure 10. Density distribution of indoleamine-accumulating neurons along a vertical intersect through the cat retina. Uptake of 5,6-DHT was performed in vitro at a concentration of $10^{-4} \mathrm{M}$. The upper curve (filled squares) shows the pooled density of all labeled neurons both in the amacrine and ganglion cell layers. It was possible to count the small brightly labeled cell bodies separately, and their density distribution is shown in the lower 2 curves. Open circles represent small cells of the amacrine layer, and open squares, small displaced amacrines of the ganglion cell layer.
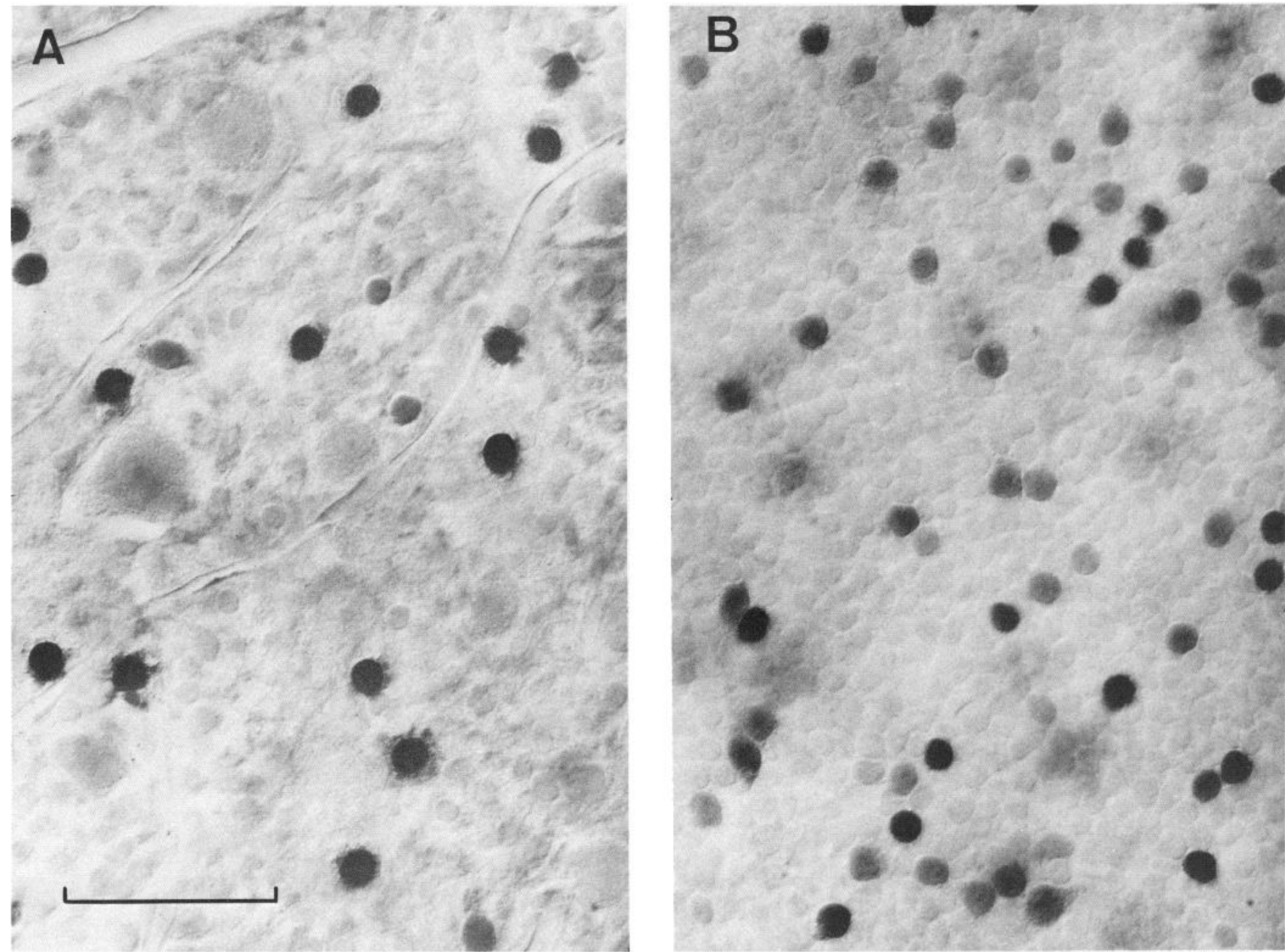

Figure 11. Micrograph showing indoleamine-accumulating neurons in the far periphery of a cat retinal whole-mount. After uptake of 5-HT, the retina was immunohistochemically stained with an antibody directed against 5-HT, and the PAP method. Dark cells are 5-HT accumulating. Using interference contrast, the nonlabeled neurons are also visible. The focus in $A$ was taken at the level of the ganglion cells, that in $B$ at the level of amacrine cells. Scale bar, $50 \mu \mathrm{m}$. 
Golgi staining in the cat retina, Kolb et al. (1981) described 22 different types of amacrine cells and 23 classes of ganglion cells. From the illustrations and descriptions of wide-field amacrine cells, their A20 amacrine cell appears to be a good match for the sparsely branched cells with brightly fluorescent cell bodies illustrated in our Figures 3 and $4 A$. Amacrine cell A20 has a small cell body, and the dendrites are smooth, straight, and radiating, and are devoid of spines and appendages. A20 branches in stratum $\mathrm{S} 2$ with a dendritic field size of $2 \mathrm{~mm}$. This description fits the sparsely branched amacrines identified in Figures 3 and 4. Kolb et al. (1981) did not describe this cell type as having a cell body displaced into the ganglion cell layer. In the present study, $67 \%$ of these cells were found in the amacrine layer, and $33 \%$ had cell bodies displaced into the ganglion cell layer.

It is also possible to correlate the spiny amacrine cells (Figs. $4 B, 6$ ) with the cells described from Golgi staining (Kolb et al., 1981). On the basis of Kolb et al.'s figure 7 and their description that these cells "give off coarse radiating dendrites which at higher magnification can be seen to bear varicosities and spines along their length," the A19 and A22 amacrine cells seem to match our spiny cells. A19 corresponds in stratification level to the nondisplaced spiny cells of Figure $6 A$, whereas A22 matches the stratification level of the displaced cells (Fig. $6 B$ ), close to the ganglion cells. Pourcho and Goebel (1983) also stained A19 amacrine cells in a combined Golgi and autoradiographic study, and these cells are likely to use GABA as their transmitter.

Holmgren-Taylor (1982) has presented ultrastructural evidence that indoleamine-accumulating amacrine cells have many reciprocal synapses with rod bipolar cell terminals. The displaced spiny amacrine cells (Fig. $6 B$ ), with their dendrites stratifying in the layer where rod bipolars terminate, are good candidates for making such synapses. However, the other amacrine classes described in the present paper were not stratified at the same level as rod bipolar endings. Hence it is postulated that they also synapse with other structures, and not just rod bipolar terminals.

The 2 amacrine cells illustrated in Figure 7, which were labeled only by doubling the 5,6-DHT dose, correspond to Kolb et al.'s A17 (1981), which has been shown to accumulate ${ }^{3} \mathrm{H}$ muscimol and is likely to be GABAergic (Pourcho and Goebel, 1983).

\section{Indoleamine-accumulating ganglion cells}

The ganglion cells stained in the present paper following uptake of 5,6-DHT seem to be a distinct morphological type, as evidenced by filling several of these cclls in a small patch of retina. It is difficult to correlate them with ganglion cells known from Golgi staining. They are comparable in cell body size $(16 \mu \mathrm{m})$ and dendritic branching pattern to delta-cells (see fig. $5 \mathrm{C}$ of Boycott and Wässsle, 1974). They appear to be similar to the G15, G19, or G23 cell of Kolb et al. (1981), but considering that dendritic field size and branching pattern change with eccentricity, a closer match is difficult.

On the basis of counterstaining the retina with cresyl violet, the proportion of indoleamine-accumulating ganglion cells was estimated to be $3-4 \%$ of all ganglion cells. Despite this low proportion, they cover the retina several times because of their rather large dendritic fields. Unfortunately, no information is available concerning the physiological type to which they correspond or their projection targets. Nonetheless, with the ex- ception of alpha- and beta-cells, no other morphological class of ganglion cell in the cat retina has been described quantitatively in such detail as the ganglion cells labeled by the uptake of indoleamines.

\section{References}

Boycott, B. B., and H. Wässle (1974) The morphological types of ganglion cells of the domestic cat's retina. J. Physiol. (Lond.) 240: $397-419$.

Dowling, J. E., B. Ehinger, and I. Florén (1980) Fluorescence and electron microscopical observations on the amine-accumulating neurons of the Cebus monkey retina. J. Comp. Neurol. 192: 665-685.

Ehinger, B. (1982) Neurotransmitter systems in the retina. Retina 2. 305-321.

Ehinger, B., and I. Florén (1976) Indoleamine-accumulating neurons in the retina of rabbit, cat and goldfish. Cell Tissue Res. 175: 37-48.

Ehinger, B., and I. Florén (1980) Retinal indoleamine accumulating neurones. Neurochem. Int. 1: 209-229.

Ehinger, B., and I. Holmgren (1979) Electron microscopy of the indoleamine-accumulating neurons in the retina of the rabbit. Cell Tissue Res. 197: 175-194.

Holmgren-Taylor, I. (1982) Electron microscopical observations on the indoleamine-accumulating neurons and their synaptic connections in the retina of the cat. J. Comp. Neurol. 208: 144-156.

Hughes, A., and E. Wieniawa-Narkiewicz (1980) A newly identified population of presumptive microneurones in the cat retinal ganglion cell layer. Nature 284: 468-470.

Kolb, H., R. Nelson, and A. Mariani (1981) Amacrine cells, bipolar cells and ganglion cells of the cat retina: A Golgi study. Vision Res. 21: 1081-1114.

Mitchell, C., and D. A. Redburn (1985) Analysis of pre- and postsynaptic factors of the serotonin system in rabbit retina. J. Cell Biol. 100: 61-103.

Negishi, K., H. Kiyama, S. Kato, T. Teranishi, S. Hatakenaka, Y. Katayama, N. Miki, and M. Tohyama (1986) An immunohistochemical study on the river lamprey retina. Brain Res. 362: 389-393.

Nelson, R., E. V. Famiglietti, Jr., and H. Kolb (1978) Intracellular staining reveals different levels of stratification for On- and Off-center ganglion cells in cat retina. J. Neurophysiol. 41: 472-483.

Osborne, N. N. (1980) In vitro experiments on the metabolism uptake and release of 5-hydroxytryptamine in bovine retina. Brain Res. 184: 283-297.

Osborne, N. N. (1984) Indoleamines in the eye with special reference to the serotonergic neurones of the retina. In Progress in Retinal Research, Vol. 3, N. N. Osborne and G. A. Chader, eds., pp. 61-103, Pergamon, New York.

Osborne, N. N., and D. W. Beaton (1986) Direct histochemical localisation of 5,7-dihydroxytryptamine and the uptake of serotonin by a subpopulation of GABA neurones in the rabbit retina. Brain Res. 382: $158-162$.

Osborne, N. N., and S. Patel (1984) Postnatal development of serotonin-accumulating neurones in the rabbit retina and an immunohistochemical analysis of the uptake and release of serotonin. Exp. Eye Res. 38: 611-620.

Osborne, N. N., T. Nesselhut, D. A. Nicholas, and A. C. Cuello (1981) Serotonin: A transmitter candidate in the vertebrate retina. Neurochem. Int. 3: 171-176.

Osborne, N. N., T. Nesselhut, D. A. Nicholas, S. Patel, and A. C. Cuello (1982) Serotonin-containing neurones in vertebrate retinas. J. Neurochem. 39: 1519-1528.

Oyster, C. W., E. S. Takahashi, M. Cilluffo, and N. C. Brecha (1985) Morphology and distribution of tyrosine hydroxylase-like immunoreactive neurons in the cat retina. Proc. Natl. Acad. Sci. USA 82 . 6335-6339.

Pourcho, R. G. (1982) Dopaminergic amacrine cells in the cat retina. Brain Res. 252: 101-109.

Pourcho, R. G., and D. J. Goebel (1983) Neuronal subpopulations in cat retina which accumulate the GABA agonist, $\left({ }^{3} \mathrm{H}\right)$ muscimol: A combined Golgi and autoradiographic study. J. Comp. Neurol. 219: 25-35.

Ranadive, N. S., and A. H. Sehon (1967) Antibodies to serotonin. Can. J. Biochem. 45: 1701-1710.

Kedburn, D. A. (1985) Serotonin neurotransmitter systems in verte- 
brate retina. In Retinal Transmitters and Modulators: Models for the Brain, Vol. 2, W. W. Morgan, ed., pp. 107-122, CRC Press, Boca Raton, FL

Sandell, J. H., and R. H. Masland (1986) $\Lambda$ system of indoleamineaccumulating neurons in the rabbit retina. J. Neurosci. 6: 3331-3347.

Steinbusch, H. W. M., A. A. J. Verhofstad, and H. W. J. Joosten (1983) Antibodies to serotonin for neuroimmunocytochemical studies on the central nervous system. Methodological aspects and applications. In IBRO Handbook: Neuroimmunocytochemistry, C. Cuello, ed., pp. 193-214, Wiley, New York.

Stewart, W. W. (1978) Functional connections between cells as revealed by dye-coupling with a highly fluorescent naphthalimide tracer. Cell 14: 741-759.

Stewart, W. W. (1981) Lucifer dyes-highly fluorescent dyes for biological tracing. Nature 292: 17-21.

Tauchi, M., and R. H. Masland (1984) The shape and arrangement of the cholinergic neurons in the rabbit retina. Proc. R. Soc. London [Biol.] 223: 101-119.

Thier, P., and H. Wässle (1984) Indoleamine-mediated reciprocal modulation of On-centre and Off-centre ganglion cell activity in the retina of the cat. J. Physiol. (Lond.) 351: 613-630.

Thomas, T. N., and D. A. Redburn (1979) 5-Hydroxytryptamine-A neurotransmitter of bovine retina. Exp. Eye Res. 28: 55-61.

Törk, I., and J. Stone (1979) Morphology of catecholamine-containing amacrine cells in the cat's retina as seen in retinal whole mounts. Brain Res. 169: 261-273.

Tornquist, K., C. Hansson, and B. Ehinger (1983) Immunohistochemical and quantitative analysis of 5-hydroxytryptamine in the retina of some vertebrates. Neurochemistry 5: 299-308.

Vakkur, G. J., and P. O. Bishop (1963) The schematic eye in the cat. Vision Res. 3: 357-381.

Vaney, D. I. (1984) "Coronate" amacrine cells in the rabbit retina have the "starburst" dendritic morphology. Proc. R. Soc. London [Biol.] 220: 501-508.

Vaney, D. I. (1986) Morphological identification of serotonin-accumulating neurons in the living retina. Science 233: 444-446.

Voigt, T. (1986) Cholinergic amacrine cells in the rat retina. J. Comp. Neurol. 248: 19-35.

Wässle, H., L. Peichl, and B. B. Boycott (1981) Morphology and topography of on- and off-alpha cells in the cat retina. Proc. R. Soc. London [Biol.] 212: 157-175.

Weilcr, R., and M. Schüttc (1985) Morphological and pharmacological analysis of putative serotonergic bipolar and amacrine cells in the retina of a turtle, Pseudemys scripta elegans. Cell Tissue Res. 241: 373-382.

Witkovsky, P., W. Eldred, and H. J. Karten (1984) Catecholamineand indoleamine-containing neurons in the turtle retina. J. Comp. Neurol. 228: 217-225. 